\title{
MULTI INFEKSI PADA UDANG Litopenaeus vannamei : DIAGNOSIS DENGAN POLYMERASE CHAIN REACTION (PCR) DAN REVERSE TRANSCRIPTASE- POLYMERASE CHAIN REACTION (RT- PCR)
}

\author{
Isti Koesharyani, Lila Gardenia, dan Hambali Supriyadi \\ Pusat Penelitian dan Pengembangan Perikanan Budidaya \\ JI. Ragunan 20, Pasar Minggu, Jakarta Selatan 12540 \\ E-mail: isti@cria.indosat.net.id; istisugama@yahoo.com
}

(Naskah diterima: 19 April 2011; Disetujui publikasi: 15 Februari 2012)

\begin{abstract}
ABSTRAK
Penelitian ini dilakukan karena adanya masalah yang dihadapi seperti pertumbuhan udang yang tidak seragam (ukuran bervariasi), penampakan klinis yang abnormal dan organ yang tidak sempurna. Gejala tersebut akibat dari infeksi penyakit yang disebabkan oleh virus. Untuk mengetahui jenis virus yang menyerang udang tersebut, maka dilakukan analisis Polymerase Chain Reaction (PCR) dan Reverse TranscriptasePolymerase Chain Reaction (RT- PCR) menggunakan berbagai jenis spesifik primer WSSV, IHHNV, MBV, TSV, IMNV, dan PVNV. Sampel udang yang secara visual normal dan abnormal diambil lalu disimpan dalam larutan pengawet $90 \%$ Ethanol dan RNAlater kemudian dianalisis di laboratorium dengan metode yang sudah dikembangkan oleh Pusat Penelitian dan Pengembangan Perikanan Budidaya. Hasilnya menunjukkan bahwa udang yang tumbuh lambat dan mempunyai rostrum bengkok dan warna otot daging memutih ternyata tidak hanya diserang oleh satu virus namun dua virus IHHNV dan IMNV. Hasil penelitian ini juga mengindikasikan bahwa udang yang terserang IHHNV akan tumbuh lambat walaupun tidak mematikan, sedangkan udang yang diserang IMNV otot daging di tubuh memutih terutama pada bagian punggung dan dapat menimbulkan kematian.
\end{abstract}

KATA KUNCI: multi infeksi Litopenaeus vannamei, IHHNV, IMNV, WSSV, PCR, RT- PCR

ABSTRACT: Multi infection of Litopenaeus vannamei shrimp: detection by using Polymerase Chain Reaction (PCR) and Reverse TranscriptasePolymerase Chain Reaction (RT- PCR) method. By: Isti Koesharyani, Lila Gardenia, and Hambali Supriyadi

This research was done due to the problems found in the field such as shrimp with abnormal growth (dwarf). Those symptoms caused the disease outbreak by viruses. To know the type of virus that infected to the shrimp, the samples be analyze by using Polymerase Chain Reaction (PCR) and Reverse Transcriptase-Polymerase Chain Reaction (RT-PCR) method with primers of specific WSSV, IHHNV, MBV, TSV, IMNV, and $P V N V$. Samples of normal and abnormal shrimp were taken and stored in a preservative solution $90 \%$ ethanol and RNAlater and then analyzed in the laboratory with a method that has been developed by The Research Center for Aquaculture. The results showed that the shrimp that grow slowly and have a curved rostrum and the white flesh muscle was infected by two type of viruses IHHNV and IMNV. The results also indicate 
that IHHNV infected shrimp will grow slowly, although there are not mortality. While the shrimp are IMNV infected by shown muscle white body, especially on the back and can cause mortality

\section{KEYWORDS: multi infection Litopenaeus vannamei, IHHNV, IMNV, WSSV,PCR, $R T$ - PCR}

\section{PENDAHULUAN}

Budidaya udang telah diketahui sangat menguntungkan, bila produksi tidak mengalami kegagalan baik dalam produksi larva di hatcheri maupun pada saat proses pertumbuhan di tambak. Namun, kenyataan yang ada di lapangan seringkali terjadi berbagai masalah, kasus tersebut adalah adanya infeksi patogen baik bakteri, jamur, maupun patogen lain yaitu virus. Patogen yang disebabkan oleh virus disinyalir merupakan kasus yang sering ditemukan dan menyebabkan kerugian karena tingkat kematian dapat mencapai $100 \%$ seperti pada kasus infeksi white spot syndrome virus (WSSV) pada budidaya udang P. monodon. Virus tersebut mempunyai inang yang sangat luas, dapat menyerang berbagai jenis udang penaeid, di antaranya $P$. monodon, $P$. japonicus, $P$. chinensis, $P$. Indicus, $P$. marguensis, dan $L$. vannamei (Kasornchandra et al., 1998, Koesharyani et al., 2001; Flegel. 1999 ; Kimura et al., 1996; Inouye et al., 1994; Rodriguez et al., 2003).

Beberapa kasus kematian massal yang disebabkan oleh penyakit pada udang vaname pernah dilaporkan terjadi di beberapa tambak baik di Jawa maupun di luar Jawa. Adapun gejalagejalanya yang pernah dilaporkan sesuai dengan jenis penyakit yang disebabkan oleh patogen virus. Menurut OIE (Aquaculture Asia Pacific, 2010), ada beberapa jenis penyakit virus yang menyerang udang dan perlu diwaspadai diantaranya (ada 9 jenis penyakit), yaitu White Spot Syndrome Virus (WSSV), Infectious Hypodermal dan Haematopoetic Necrosis (IHHNV), Penaeus monodon-type baculovirus (MBV), Taura syndrome virus (TSV), Yellow head virus (YHV), Infectious myonecrosis virus (IMNV), Hepatopancreatic parvovirus (HPV), Gill associated virus (GAV), dan Macrobrachium rosenbergii noda virus (MrNV). Di mana dari kesembilan jenis virus tersebut enam jenis virus (WSSV, IHHNV, MBV, YHV, IMNV, dan TSV) sudah menginfeksi secara definitif pada budidaya udang P. monodon dan L. vannamei di Indonesia. Namun tidak tertutup kemungkinan akan adanya infeksi penyakit baru yang akan menginfeksi bila pencegahan dengan cara diagnosis rutin tidak dilakukan. Sementara infeksi jenis virus tersebut diketahui sangat mematikan sehingga dapat menimbulkan kerugian ekonomi yang tidak sedikit.

Infeksi WSSV sangat ganas dan mematikan pada budidaya udang windu $P$. monodon, sedangkan pada udang L. vannamei yang berasal dari Amerika ternyata rentan terhadap serangan penyakit Taura Syndrome Virus (TSV) infeksi. Penyakit ini diketahui sejak tahun 1992 di Ecuador (Poulos et al., 1999). Penyakit lain yang dapat menyerang udang L. vannamei adalah Infectious Myonecrosis Virus (IMNV) dan diketahui sejak tahun 2004 di Brazil. Kasus IMNV pertama di Indonesia dilaporkan telah menginfeksi budidaya udang L. vannamei pada tahun 2006 di Situbondo Jawa Timur (Senapin et al., 2007) dan infeksi tersebut sampai saat ini masih sering ditemukan pada tambak yang bermasalah. Penyakit lain yang dianggap terbaru yang sudah diketahui di Belize pada tahun 2004 juga menyerang udang putih ini adalah Penaeus vannamei Noda Virus (PvNV), serangan virus ini dapat mengakibatkan nekrosia pada daging atau muscle necrosis, gejala ini hampir sama seperti serangan IMNV (Tang et al., 2007b). Umumnya udang $L$. vannamei ini rentan terhadap infeksi golongan RNA virus (TSV, IMNV, dan PvNV) dan beberapa golongan DNA virus seperti WSSV dan IHHNV (OIE, 2006). Untuk virus lain seperti YHV dan MBV masing- masing pernah ditemukan, tetapi intensitas infeksi tidak seperti pada virus lainnya. Pada tahun 2009 kasus infeksi MBV masih ditemukan pada budidaya udang $P$. monodon organik di Sidoarjo, Jawa Timur (Koesharyani et al., 2009 unpublish).

Dengan banyaknya kejadian infeksi penyakit di lapangan khususnya virus, maka perlu dilakukan pemantauan dan diagnosis guna mencegah masuknya patogen baru yang akan memperparah kondisi perudangan di Indonesia. Oleh karena itu, untuk mengetahui adanya patogen maka perlu dilakukan analisis 
deteksi rutin menggunakan PCR dan RT- PCR menggunakan berbagai macam spesifik primer. Diharapkan hasil yang diperoleh dapat menentukan status penyakit sehubungan dengan pengembangan udang introduksi $L$. vannamei.

\section{BAHAN DAN METODE}

\section{Sampel Udang L. vannamei}

Sampel udang L. vannamei normal dan abnormal yang berumur \pm 2 bulan berasal dari lokasi budidaya udang di Situbondo, Jawa Timur. Sampel udang diambil dengan gejala seperti ukuran yang tidak seragam walaupun berumur sama, abnormalitas bentuk rostrum (memendek dan bengkok) serta warna tubuh yang memutih. Sampel selanjutnya disimpan dalam dua larutan pengawet yang berbeda yaitu pada $90 \%$ Ethanol untuk digunakan dalam pengujian DNA virus dengan metode PCR, dan RNAlater ${ }^{\circledast}$ (Qiagen), untuk digunakan dalam analisis RNA virus dengan metode RT-PCR. Pada setiap individu sampel udang kemudian diekstrak DNA dan RNA nya. (Ektraksi DNA dan RNA dilakukan pada setiap individu sampel udang).

\section{Ekstraksi DNA}

Persiapan lysate: Masing- masing sampel udang uji diambil jaringan insang/pleopod seberat $10 \mathrm{mg}$, dimasukkan dalam $(2 \mathrm{~mL})$ mikrotube Precellys Ceramic ditambahkan 250 $\mu \mathrm{L}$ Lysis buffer (Mole product). Jaringan udang dihancurkan dengan alat Homogenizer PeqLab dengan kecepatan 5000 rpm selama 3 menit dengan penghentian kecepatan tiap 1 menit sebanyak 3 kali. Selanjutnya homogenat diinkubasi pada suhu $37^{\circ} \mathrm{C}$ selama 1 jam. Sebanyak $10 \mu \mathrm{L}$ Rnase A (Dnase \& Protease Free) $10 \mathrm{mg} / \mathrm{mL}$ ditambahkan untuk menghilangkan RNA dan protein sebagai penghambat amplifikasi dan inkubasikan kembali pada suhu $37^{\circ} \mathrm{C}$ selama kurang lebih 45 menit kemudian ditambahkan $10 \mu \mathrm{L}$ Proteinase- $\mathrm{K}(10 \mathrm{mg} / \mathrm{mL})$ dan diinkubasi pada suhu $55^{\circ} \mathrm{C}$ satu malam, selanjutnya lysate yang diperoleh akan digunakan pada proses isolasi genom DNA.

Isolasi genom DNA: Isolasi genom DNA dilakukan dengan Gen Mole Strip ${ }^{\mathrm{TM}}$ DNA Tisue secara Robotik, yaitu dengan memindahkan sebanyak $\pm 200 \mu$ L Lysate (supernatan) yang telah diperoleh dari ektraksi ke dalam tabung Strip Mole dan ditempatkan sedemikian rupa dalam rak pada mesin robotik kemudian diprogram dan dioperasikan selama 45 menit. Hasil akhir berupa $100 \mu \mathrm{L}$ genom DNA, selanjutnya dipindahkan ke dalam mikrotube steril (DNAse \& Rnase Free). Genom DNA digunakan untuk amplifikasi DNA virus target dengan menggunakan PCR dan spesifik primer.

\section{Ekstraksi RNA}

Persiapan lysate: Sampel udang uji diambil jaringan insang/pleopod seberat 25 $\mathrm{mg}$, dimasukkan dalam $(2 \mathrm{~mL})$ mikrotube Precellys Ceramic ditambahkan $600 \mu \mathrm{L}$ Lysis Buffer (Mole product). Jaringan udang dihancurkan dengan alat Homogenizer PeqLab dengan kecepatan 5000 rpm selama 3 menit sebanyak 2 kali, homogenat diinkubasikan pada suhu ruang selama 10-15 menit, kemudian di-sentrifugasi dengan kecepatan 14000 rpm selama 1 menit. Sebanyak $600 \mu \mathrm{L}$ supernatan diambil dan ditempatkan ke dalam mikrotube baru dan ditambahkan $600 \mu \mathrm{L}$ Ethanol $80 \%$

Isolasi Genom RNA: Isolasi genom RNA dilakukan dengan menggunakan SurePrep ${ }^{\mathrm{TM}}$ True Total ${ }^{\mathrm{TM}}$ RNA purification Kit (Fisher Bio Reagent), proses awal isolasi adalah pengikatan genom RNA dengan memasukkan $2 \times 600 \mu \mathrm{L}$ lysate dalam spin column dan disentrifugasi masing-masing dengan kecepatan 14000 rpm selama 1 menit, setelah RNA terikat pada spin column selanjutnya dilakukan proses pencucian RNA.

Pencucian (washing), ke dalam spin column ditambahkan $400 \mu \mathrm{L}$ wash solutian kemudian disentrifugasi dengan kecepatan 14000 rpm selama 1 menit. Proses tersebut dilakukan sebanyak tiga kali pada pencucian yang ketiga, lama sentrifugasi menjadi 2 menit. Column dibiarkan sebentar hingga kering kemudian dilanjutkan dengan proses pencairan RNA.

Pencairan RNA (RNA Elution). Pada proses pencairan RNA column dipindahkan ke dalam mikrotube steril (DNAse \& RNAse Free) dan ditambahkan $100 \mu \mathrm{L}$ pelarut RNA yang ada dalam kit. Kemudian mikrotube berisi column disentrifugasi dengan kecepatan 1500 rpm selama 2 menit. Sentrifugasi dilanjutkan dengan kecepatan 12000 rpm selama 1 menit. Genom RNA yang diperoleh selanjutnya digunakan untuk amplifikasi cDNA dengan RTPCR menggunakan spesifik primer. 
Tabel 1. Primer spesifik yang digunakan dalam mendeteksi beberapa jenis virus yang menginfeksi udang $L$. vannamei

Table 1. The specific primers used to detect of several types of viruses infected on $\boldsymbol{L}$. vannamei shrimp

\begin{tabular}{|c|c|c|}
\hline $\begin{array}{l}\text { Jenis virus } \\
\text { Type of virus }\end{array}$ & $\begin{array}{l}\text { Sekuen primer } 5^{\prime} \sim 3^{\prime} \\
\text { Primers sequences } 5^{\prime} \sim 3^{\prime}\end{array}$ & $\begin{array}{l}\text { Ukuran amplikon } \\
\text { Amplicon size } \\
\text { (bp) }\end{array}$ \\
\hline WSSV & $\begin{array}{l}\text { R: 5'- AgA Tag CgA AAC AAC ATC CAA C-3' } \\
\text { F: 5'- ATg gTA CAT TTT CCg ggC g -3' }\end{array}$ & $\begin{array}{c}113 \\
\text { Gen Bank U50923.1 }\end{array}$ \\
\hline IHHNV & $\begin{array}{l}\text { R: 5' - ggC CAA gAC CAA AAT ACg AA -3' } \\
\text { F: 5' - Cgg AAC ACA ACC CGA CTT TA -3' }\end{array}$ & $\begin{array}{c}389 \\
\text { Tang et al. (2007) (a) } \\
\text { Gen Bank.AF218266 }\end{array}$ \\
\hline MBV & $\begin{array}{l}\text { R: 5' - Tgg CAT gCA CTC CCT gAg AT -3 } \\
\text { F: 5' - CAT ATC ggC CgA ATA gTg gTC -3' }\end{array}$ & $\begin{array}{l}526 \\
\text { Jena Germany }\end{array}$ \\
\hline TSV & $\begin{array}{l}\text { R: 5'- AAg TAg ACA gCC gCg CTT gC-3' } \\
\text { F: 5'-TCA ATg AgA gCT Tgg TCC-3' }\end{array}$ & $\begin{array}{c}231 \\
\text { Nunan et al. (1998) } \\
\text { Gen Bank AF277675 } \\
\text { Nt.6910-7140 }\end{array}$ \\
\hline IMNV & $\begin{array}{l}\text { R: 5'- TgA AAA, ATA AGC TgT gCC CCA TgT T-3' } \\
\text { F: 5'-ggC AAT TTC AAC CTA ATT CTA AAA C-3' }\end{array}$ & $\begin{array}{c}600 \\
\text { Senapin et al. (2007) } \\
\text { Gen Bank EF061744 }\end{array}$ \\
\hline PvNV & $\begin{array}{l}\text { R: 5'- CCg TTT gAA TTT CAg CAA CA -3' } \\
\text { F: 5'- CTg TCT CAC Agg CTg gTT CA-3' }\end{array}$ & $\begin{array}{c}339 \\
\text { Tang et al. (2007) (b) }\end{array}$ \\
\hline
\end{tabular}

Konsentrasi DNA/ RNA: DNA diukur kwalitas dan kuantitasnya dengan menggunakan alat pengukur DNA "nanodrop". Kemurnian DNA diukur pada panjang gelombang 260 dan 280 $\mathrm{nm}\left(\mathrm{OD}_{260 / 280}=1.6-1.8\right)$. DNA dan RNA yang baik dalam jumlah dan kemurniannya selanjutnya digunakan pada proses amplifikasi dengan PCR.

\section{Amplifikasi DNA}

Amplifikasi PCR untuk jenis infeksi dari virus DNA dilakukan dengan menggunakan $5 x$ Green GoTaq Flexi Reaction Buffer (Promega). Amplifikasi dilakukan dengan total reaksi 10 $\mu \mathrm{L}$. Sebanyak $1 \mu \mathrm{L}$ DNA (10 ng) ditambahkan mastermix dengan konsentrasi $3,5 \mathrm{mM} \mathrm{MgCl}{ }_{2}$, $0,3 \mathrm{mM}$ dNTP mix, 0,5 pM masing-masing Reverse dan Forward primer, 0,5 U GoTaa Polymerase (Promega) dan 1 x Green GoTag Reaction Buffer (Promega). Proses amplifikasi menggunakan mesin PCR SpeedyCycler (Tretiakov \& Saluz US Patent 6.556.940). Profil amplifikasi untuk masing- masing virus IHHNV dan MBV dapat dilihat pada Tabel 2, sedangkan untuk WSSV dapat dilihat pada Tabel 3.

\section{Amplifikasi c- DNA dengan RT- PCR}

Amplifikasi untuk virus- virus RNA dilakukan dengan menggunakan AccssQuick ${ }^{\mathrm{TM}}$ RT- PCR System Promega. Amplifikasi dilakukan dengan total reaksi sebanyak $10 \mu \mathrm{L}: 2 \mu \mathrm{L}$ DNA (10 ng) ditambahkan mastermix dengan konsentrasi, 0,5 pM masing- masing Reverse dan Forward primer, dan 0,2 x AccssQuick ${ }^{\mathrm{TM}}$ Master mix (Promega). Untuk mendiagnosa atau mengamplifikasi c- DNA virus menggunakan mesin PCR SpeedyCycler (Tretiakov \& Saluz US Patent 6.556.940) profil amplifikasi untuk masingmasing virus IMNV, TSV, dan PVNV dapat dilihat pada Tabel 4.

\section{Elektroforesis}

Hasil amplifikasi selanjutnya dielektrophoresis pada $2 \%$ agarose gel, dengan larutan SB-Buffer $(10 \times 100 \mathrm{mM} \mathrm{NaOH}$ yang di- 
Tabel 2. Profil suhu amplifikasi untuk mendeteksi IHHNV dan MBV dengan PCR

Table 2. Temperature profile amplification for IHHNV and MBV detection by PCR

\begin{tabular}{|c|c|c|c|}
\hline $\begin{array}{l}\text { Kondisi } \\
\text { Condition }\end{array}$ & $\begin{array}{c}\text { Temperatur } \\
\text { Temperature }\left({ }^{\circ} \mathrm{C}\right)\end{array}$ & $\begin{array}{l}\text { Waktu (detik) } \\
\text { Time (second) }\end{array}$ & $\begin{array}{l}\text { Siklus } \\
\text { Cycle }\end{array}$ \\
\hline Denaturasi awal & 95 & 120 & 1 \\
\hline \multicolumn{4}{|l|}{ Pre-denaturation } \\
\hline Denaturasi & 95 & 10 & 45 (IHHNV) \\
\hline \multicolumn{4}{|l|}{ Denaturation } \\
\hline Penempelan & 58 & 10 & \\
\hline \multicolumn{4}{|l|}{ Annealing } \\
\hline Pemanjangan & 72 & 20 & 35 (MBV) \\
\hline \multicolumn{4}{|l|}{ Extension } \\
\hline Pemanjangan akhir & 72 & 120 & 1 \\
\hline Final elongation & & & \\
\hline
\end{tabular}

Tabel 3. Profil suhu amplifikasi untuk mendeteksi WSSV dengan PCR

Table 3. Temperature profile amplification for WSSV detection by PCR

\begin{tabular}{|c|c|c|c|}
\hline $\begin{array}{l}\text { Kondisi } \\
\text { Condition }\end{array}$ & $\begin{array}{c}\text { Temperat ur } \\
\text { Temperature }\left({ }^{\circ} \mathrm{C}\right)\end{array}$ & $\begin{array}{l}\text { Waktu (detik) } \\
\text { Time (second) }\end{array}$ & $\begin{array}{c}\text { Siklus } \\
\text { Cycle }\end{array}$ \\
\hline Denaturasi awal & 95 & 120 & 1 \\
\hline \multicolumn{4}{|l|}{ Pre-denaturation } \\
\hline Denaturasi & 95 & 5 & \\
\hline Denaturation & & & \multirow{2}{*}{45} \\
\hline Penempelan/ Pemanjangan & 60 & 20 & \\
\hline \multicolumn{4}{|l|}{ Annealing/Extension } \\
\hline Pemanjangan akhir & 72 & 120 & 1 \\
\hline Final elongation & & & \\
\hline
\end{tabular}

Tabel 4. Profil suhu amplifikasi untuk mendeteksi IMNV, TSV, dan PVNV dengan PCR Table 4. Temperature profile amplification for IMNV, TSV, and PVNV detection by PCR

\begin{tabular}{lccc}
\hline \multicolumn{1}{c}{$\begin{array}{c}\text { Kondisi } \\
\text { Condition }\end{array}$} & $\begin{array}{c}\text { Temperatur } \\
\left.\text { Temperature ( }{ }^{\circ} \mathbf{C}\right)\end{array}$ & $\begin{array}{c}\text { Waktu (detik) } \\
\text { Time (second) }\end{array}$ & $\begin{array}{c}\text { Siklus } \\
\text { Cycle }\end{array}$ \\
\hline Transkripsi terbalik & 48 & 120 & 1 \\
$\begin{array}{l}\text { Reverse transcriptation } \\
\text { Denaturasi awal }\end{array}$ & 95 & 20 & \\
$\begin{array}{l}\text { Pre-denaturation } \\
\text { Penempelan } \\
\text { Annealing }\end{array}$ & 95 & 10 & 40 \\
$\begin{array}{l}\text { Pemanjangan } \\
\text { Extension }\end{array}$ & $58(\mathrm{IMNV} \& \mathrm{TSV})$ & & \\
$\begin{array}{l}\text { Pemanjangan akhir } \\
\text { Final elongation }\end{array}$ & $55(\mathrm{PVNV})$ & 10 & \\
\hline
\end{tabular}


tambahkan $\mathrm{H}_{3} \mathrm{BO}_{3}$ atau Boric Acid sampai pH 8). Hasil elektroforesis selanjutnya didokumentasikan menggunakan Geldoc.

\section{HASIL DAN BAHASAN}

Sampel udang yang diperoleh pada bulan Juli 2009 dengan lama pemeliharaan sekitar 2 bulan berasal dari tambak dengan dasar beton, menggunakan sistem sirkulasi dan tandon. Benih udang L. vannamei yang ditebar di tambak sekitar PL 10-12, berasal dari induk Spesifik Pathogen Free (SPF) dengan kepadatan berkisar 80- 100 ekor/ $\mathrm{m}^{2}$.

Gejala udang sakit yang ditemukan di lapangan adalah adanya nekrosa pada otot bagian atas perut dan ekor disertai warna putih pada bagian otot punggung ke arah ekor juga nekrosia di ujung- ujung ekor (Gambar 1). Hasil pengamatan juga diperoleh adanya pertumbuhan udang yang tidak seragam atau ukuran yang bervariasi dan disertai bentuk rostrum yang abnormal atau bengkok (Gambar 2). Kondisi udang di lapangan hampir semua menampakkan gejala yang sama, seperti telah dijelaskan di atas. Oleh karena itu, untuk pengujian dalam penelitian hanya diambil beberapa contoh (8 ekor udang) yang dapat mewakili kondisi atau keadaan udang di lapangan.

Berdasarkan sampel yang diperoleh baik yang sehat secara visual maupun yang sakit, setelah dilakukan diagnosa beberapa jenis virus (WSSV, IHHNV, MBV, TSV, IMNV, dan PVNV)
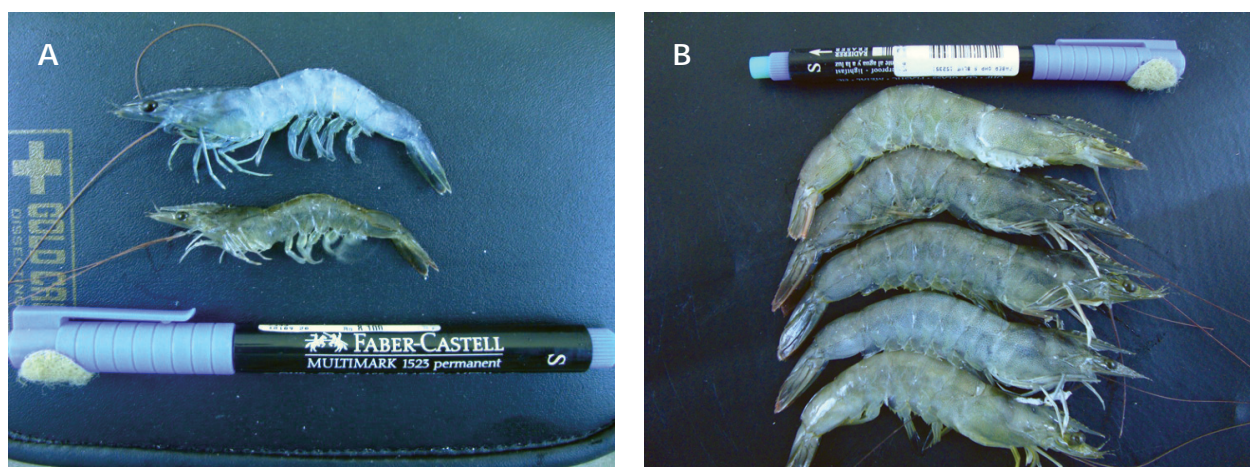

Gambar 1. Sampel udang L. vannamei dengan gejala warna udang putih (opaque) dan kerdil (A) disertai necrosia pada ekor (B)

Figure 1. Samples of $L$. vannamei shrimp with symptoms of white shrimp color (opaque) and stunted (A), necrosia accompanied on the tail and (B)
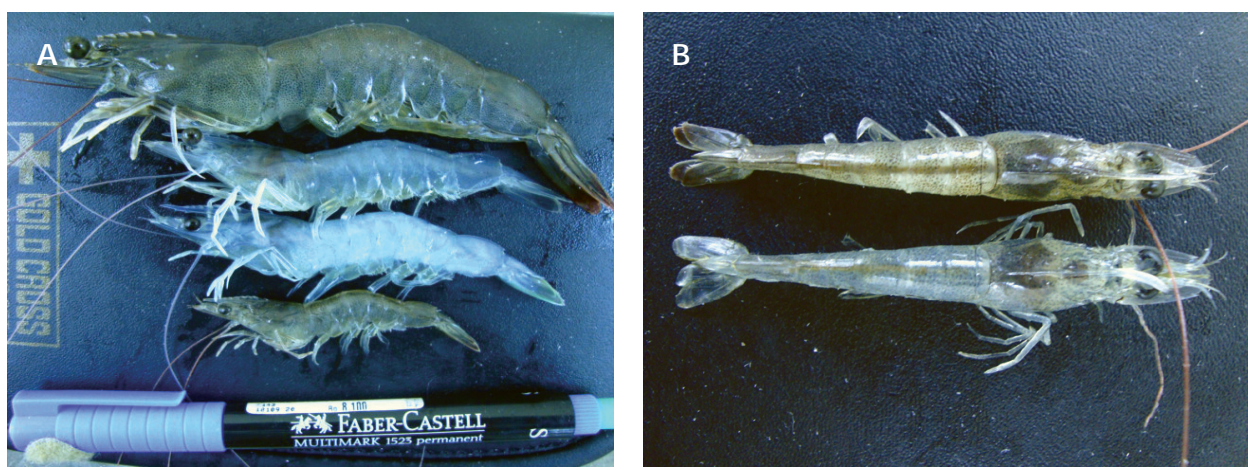

Gambar 2. Sampel udang L. vannamei yang digunakan (A) normal, abnormal dan ukuran udang yang tidak seragam, (B) rostrum yang bengkok

Figure 2. Samples of $\boldsymbol{L}$. vannamei shrimp were used testing $(A)$ healthy, normal, abnormal and the size of shrimp that are not uniform, (B) and a bend rostrum 
menggunakan teknik PCR dan RT- PCR dengan spesifik primer (Tabel 1) ternyata menunjukkan adanya infeksi. Hasil yang diperoleh menunjukkan bahwa 75\% sampel terinfeksi oleh IMNV dan $100 \%$ sampel terinfeksi IHHNV. Dari perhitungan diagnosa ternyata tidak sedikit (75\%) udang uji terinfeksi oleh kedua jenis virus secara bersamaan IHHNV dan IMNV (Tabel 5). Kasus natural multi infeksi ini sering ditemukan pada udang penaeid, walaupun variasi jenis virus berbeda pada setiap kasus. Hal ini ditunjukkan seperti pada kasus multi infeksi WSSV dan MBV yang ditemukan pada budidaya udang $P$. monodon di Philippine (Natividad et al., 2006). Bahkan ditemukan kasus 'triple infection', 3 jenis virus MBV, HPV, dan WSSV pada P. monodon di India walaupun MBV dan HPV difinitif positif dengan pemeriksaan histopatologi dan WSSV positif dengan single step PCR (Manivannan et al., 2002).

Infeksi IMNV pada budidaya tambak udang L. vannamei sampai saat ini masih sering terjadi dengan intensitas yang cukup tinggi terjadi hampir setiap tahun baik di Jawa maupun di luar Jawa. Monitoring yang dilakukan pada awal tahun 2010 diperoleh kasus kematian dengan gejala TSV dan IMNV pada tambak L. vannamei di Banyuwangi, Jawa Timur (Laporan monitoring 2010 unpublish). Infeksi IMNV pada budidaya udang L. vannamei yang teridentifikasi pada tahun 2004 juga merupakan kasus infeksi yang cukup merugikan. Keberadaan penyakit tersebut akan terus berada selama dalam pertumbuhan udang di tambak, dan secara kumulatif akibat infeksi
IMNV ini dapat mematikan udang budidaya sampai dengan $70 \%$ (Nunes et al. dalam Poulos et al., 2006; Poulos \& Lightner, 2006). Hasil pengujian infeksi buatan terhadap infeksi IMNV menunjukkan bahwa IMNV dapat menginfeksi pada ketiga jenis udang $L$. vannamei, $L$. stylirostris, dan $P$. monodon walaupun mempunyai efek yang berbeda (Tang et al., 2005) dan kemungkinan dapat menyerang udang penaid lainnya. Dalam nomenklatur virus, IMNV ini termasuk ke dalam RNA virus double-stranded, family Totaviridae, yang tidak beramplop (non-enveloped), berbentuk icosahedral dengan diameter virion $40 \mathrm{~nm}$ (Senapin et al., 2007).

Akurasi deteksi virus agar mendapatkan hasil yang maksimal dengan menggunakan teknik PCR/RT-PCR, yang ditentukan oleh beberapa faktor, seperti penyimpanan sampel pada larutan yang tepat dan ketepatan jenis primer yang digunakan. Penyimpanan jaringan untuk pemeriksaan virus dari gol RNA seperti TSV, IMNV, dan PVNV dan Iain-lain dalam larutan ethanol $90 \%$ bisa mengalami kerusakan sehingga tidak dapat dideteksi kembali adanya patogen virus. Sebaiknya sampel untuk golongan RNA virus disimpan dalam larutan RNAlater, dari hasil percobaan ternyata RNAlater dapat menjaga kestabilan RNA dan dari hasil pengamatan preservasi penggunaan sampel jaringan yang disimpan selama 1 tahun dalam larutan RNAlater pada suhu $-20^{\circ} \mathrm{C}$ keadaan RNA masih tetap baik dan stabil dibandingkan dengan penyimpanan jaringan dalam larutan Ethanol 90\%(Novita et al., 2009).

Tabel 5. Hasil diagnosa enam jenis virus WSSV, MBV, IHHNV, TSV, IMNV, dan PVNV pada udang L. vannamei

Table 5. Diagnostic results of six types of viruses WSSV, MBV, IHHNV, TSV, IMNV, and PVNV on L. vannamei shrimp

\begin{tabular}{|c|c|c|c|c|c|c|}
\hline \multirow{2}{*}{$\begin{array}{c}\text { Sampel udang vaname } \\
\text { Shrimp samples L. vannamei }\end{array}$} & \multicolumn{6}{|c|}{ Diagnostik virus ( Viruses detection) } \\
\hline & WSSV & MBV & IHHNV & TSV & IMNV & PVNV \\
\hline Normal & - & - & + & - & + & - \\
\hline Abnormal (Dwarf) & - & - & + & - & - & - \\
\hline Normal & - & - & + & - & + & - \\
\hline Abnormal (Whit ish) & - & - & + & - & + & - \\
\hline Normal & - & - & + & - & + & - \\
\hline Abnormal (Whit ish) & - & - & + & - & + & - \\
\hline Abnormal curved-rostrum & - & - & + & - & - & - \\
\hline Abnormal (Whitish) & - & - & + & - & + & - \\
\hline
\end{tabular}


Pemilihan dan ketepatan primer juga sangat menentukan hasil diagnosa. Ada beberapa jenis primer yang dapat digunakan dalam mendiagnosa IMNV. Dalam percobaan ini, primer IMNV yang digunakan adalah primer yang didesain oleh (Senapin et al., 2007) dengan target berat molekul $600 \mathrm{bp}$. Primer tersebut mempunyai sensitivitas yang lebih baik dibandingkan primer lain yang pernah ada (Poulos \& Lightner, 2006). Pada penelitian ini penggunaan spesifik primer dengan target berat molekul 600 bp. merupakan hasil sekuen dari udang L. vannamei yang terinfeksi IMNV di Indonesia sehingga keberhasilan dalam mendeteksi adanya IMNV akan lebih spesifik dan tidak menghasilkan false negative (negatif palsu). Sekuen susunan nukleotida yang berasal dari IMNV Indonesia ini sudah dimasukkan ke dalam Gen Bank dengan accession no. EF061744 (Senapin et al., 2007). Hasil analisis sampel uji dengan RT-PCR menggunakan primer IMNV dapat dilihat pada Gambar 3.

Kasus lain yang ditemukan pada penelitian ini yaitu adanya infeksi IHHNV. Dari sampel yang diperoleh dari lapangan baik itu udang yang terlihat sehat maupun sakit, ternyata sampel uji tersebut terinfeksi $100 \%(8 / 8)$ oleh IHHNV. Diketahui bahwa IHHNV dapat mematikan dan sangat patogen terhadap udang jenis L. stylirostris (Lightner \& Redman, 1998). Virus tersebut diketahui tidak mematikan bila menginfeksi udang L. vannamei atau $P$. monodon, namun IHHNV hanya menyebabkan pertumbuhan yang lambat dan pertumbuhan rostrum yang abnormal (bengkok) (Tang et al., 2007a; Bonnichon et al., 2006; Flegel et al., 2004; Tang et al., 2003; Kalagayan et al., 1991). Hal tersebut sama seperti kasus yang diperoleh dalam penelitian ini, udang menampakkan gejala pertumbuhan yang tidak normal dengan beragam ukuran disertai bentuk rostrum yang abnormal atau bengkok (Gambar 2). Walaupun infeksi IHHNV tidak mematikan pada udang tetapi dapat menimbulkan kerugian ekonomi oleh karena terjadi peningkatan Feed Conversion Ratio (FCR) pakan. Berdasarkan karakteristik morfologi dan biokimia, IHHNV termasuk ke dalam golongan Parvoviridae dengan bentuk icosahedral DNA non-enveloped yang berdiameter 22 nm (Bonami et al., 1990). Dari hasil penelitian menyatakan bahwa penyebaran virus IHHNV dapat diturunkan secara vertikal melalui induk betina, yaitu pada ovari udang betina yang terinfeksi. Sementara dari sperma udang jantan yang positif IHHNV tidak menurunkan IHHNV. Dengan demikian IHHNV ini diturunkan dari induk betina yang positif

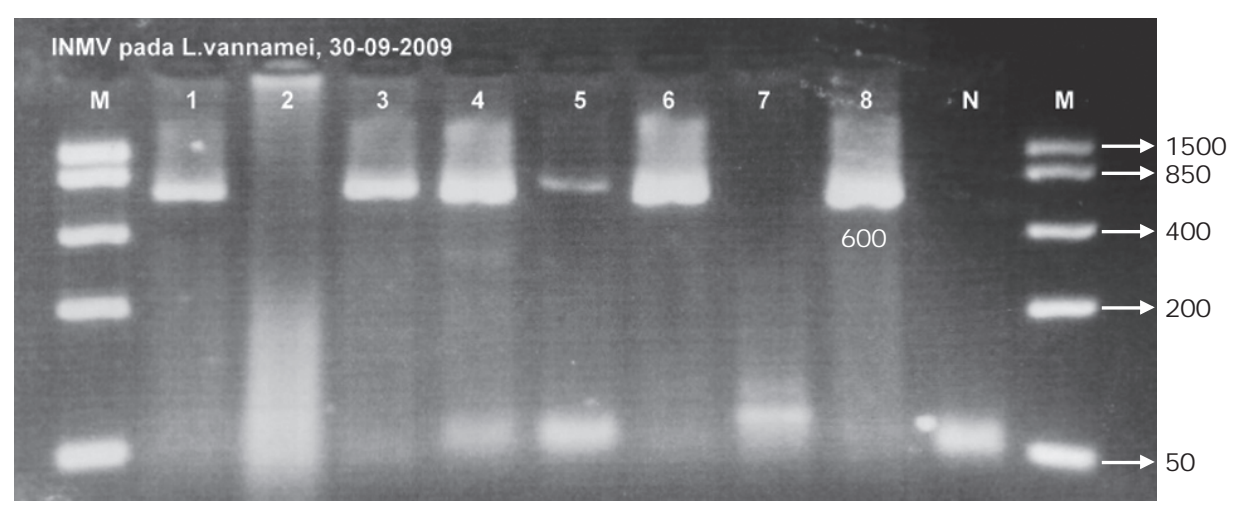

Gambar 3. Profil amplifikasi PCR sampel udang L. vannamei yang terinfeksi IMNV pada target berat molekul 600 bp. 1: Normal; 2: Abnormal/dwarf; 3: Normal; 4: Abnormal/ whitish; 5: Normal; 6: Abnormal/ whitish; 7: Abnormal/curved rostrum; 8: Abnormal/ whitish, N: Negative Control, M: Marker Low Range

Figure 3. Profile of PCR amplification of shrimps samples $\mathbf{L}$. vannamei infected IMNV on the target molecular weight of $600 \mathrm{bp}$. 1: Normal; 2: Abnormal/ dwarfs; 3: Normal; 4: Abnormal/whitish; 5: Normal; 6: Abnormal/whitish; 7: Abnormal/curved rostrum; 8: Abnormal/whitish, $\mathrm{N}$ : Negative Control, M: Marker Low Range 
terinfeksi IHHNV (Motte et al., 2003). Oleh karena itu, dalam persiapan perbenihan udang, pemeriksaan induk yang akan digunakan untuk produksi larva dalam hatcheri harus benarbenar diperhatikan terutama dalam mendeteksi ada- tidaknya infeksi khususnya IHHNV pada induk betina yang akan digunakan dalam pembenihan.

Ada beberapa jenis primer yang dapat digunakan dalam deteksi secara rutin terhadap IHHNV (OIE, 2006; Tang et al., 2003; Tang et al., 2007a) dan teknik deteksi lain seperti Ramification Amplification Assay (RAM) yang bisa digunakan dalam alternatif deteksi (Teng et al., 2006). Dalam penelitian diagnostik IHHNV, digunakan spesifik primer yang sangat sensitif dan tercatat dalam Gen Bank dengan Asseccion No AF 218266 dengan target berat molekul 389 bp. Primer ini bisa digunakan untuk mendiagnosa semua jenis IHHNV dari lokasi berbagai negara serta dapat digunakan untuk deteksi rutin (Tang et al., 2007a). Telah dijelaskan di atas bahwa sampel udang yang kelihatan sehat (normal) dan abnormal pada penelitian ini ternyata positif terinfeksi IHHNV. Hasil diagnostik dapat dilihat dari hasil amplifikasi dengan PCR (Gambar 4).

Infeksi IHHNV yang ditemukan bersamaan dengan infeksi IMNV pada sampel L. vannamei ini, tidak menyebabkan kematian yang berarti. Fenomena ini kemungkinan disebabkan oleh adanya kompetisi atau perbedaan pola replikasi virion pada kedua virus tersebut di dalam seluler tubuh udang. Kasus seperti ini pernah terjadi pada percobaan infeksi buatan WSSV pada L. vannamei yang positif IHHNV, dimana tingkat kematian adanya infeksi WSSV dapat dihambat karena kemungkinan terganggunya WSSV dalam mereplikasi didalam tubuh udang dibandingkan dengan infekesi WSSV ke L. vannamei yang negatif terinfeksi IHHNV. (Bonnichon et al., 2006; Melena et al., 2006). Kondisi ini sama dengan apa yang ditemukan pada kasus yang terjadi pada udang sampel yang dianalisis pada tulisan ini. Di mana kematian yang terjadi tidak terlalu banyak, kemungkinan kasus ini adanya fenomena tersebut di atas. Akibatnya adalah ukuran udang yang sangat bervariasi karena adanya infeksi IHHNV dan penampilan udang yang tidak begitu cerah akibat infeksi IMNV. Oleh karena itu, kualitas penggunaan induk sangat perlu diperhatikan didalam melakukan pembenihan udang vanname. Pencegahan adalah tindakan yang harus dilakukan dengan cara melakukan deteksi dan monitoring adanya patogen penyakit.

Untuk pencegahan dapat dilakukan dengan cara mendeteksi dengan baik dan benar. Saat ini telah berkembang teknik deteksi atau diagnosa dengan Real-Time PCR atau Quantitatif PCR (Q- PCR). Teknik tersebut

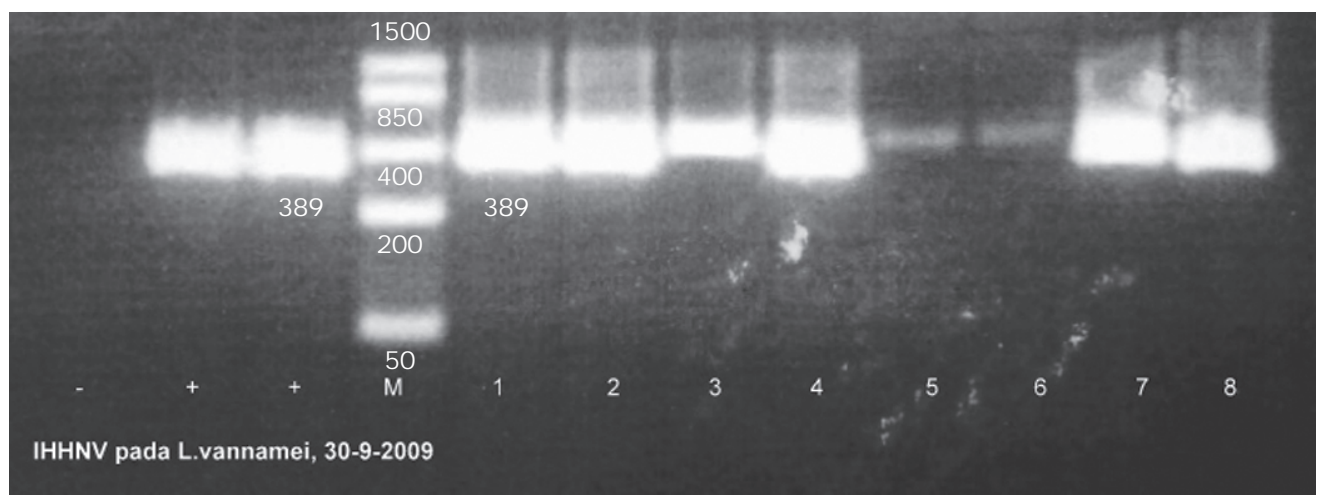

Gambar 4. Profil amplifikasi PCR sampel udang L. vannamei yang terinfeksi IHHNV pada target berat molekul 389 bp. 1: normal; 2: abnormal/ dwarf; 3: Normal; 4: abnormal/ whitish; 5: normal; 6: abnormal/ whitish; 7: abnormal/curved rostrum; 8: abnormal/ whitish, M: marker low range, (-): negative control, (+): positive control

Figure 4. Profile PCR amplification samples of shrimps IHHNV-infected L. vannamei on the target molecular weight of 389 bp. 1: normal; 2: abnormal/dwarfs; 3: normal; 4: abnormal/whitish; 5: normal; 6: abnormal/whitish; 7: abnormal/curved rostrum; 8: abnormal/whitish, M: marker low range, (-): negative control, (+):positive control 
mempunyai keunggulan yaitu tingkat sensitivitas yang sangat tinggi selain mendeteksi secara kwalitatif juga dapat mengetahui kwantitas virion di dalam individu yang terinfeksi oleh suatu virus. Pada individu dengan serangan awal suatu infeksi virus, maka dengan mudah dapat diketahui adanya infeksi walaupun dalam jumlah virion sangat sedikit/kecil. Teknik tersebut dapat diaplikasikan pada ikan atau hewan lain yang bersifat carrier. Teknik Real-Time PCR ini sudah banyak diterapkan di antaranya dalam mendiagnosa virus IHHNV dan WSSV pada udang (Dhar et al., 2001), sedangkan pada ikan tawar Koi digunakan dalam mendeteksi infeksi KHV (Gilad et al., 2004).

Selain itu menurut Tang et al. (2007b), mengatakan bahwa terdapat kasus infeksi baru yang dapat menyerang udang yang dinamakan P. vannamei Nodavirus atau PvNV. Walaupun sampai saat ini di Indonesia kasus infeksi PvNV tersebut belum pernah ditemukan, namun tidak tertutup kemungkinan akan adanya penyebaran, sehingga dapat berakibat merugikan dalam budidaya udang $L$. vannamei. Dengan ketersediaan induk $L$. vannamei yang sudah didomestikasi dan tersertifikasi bebas virus (WSSV, IHHNV, TSV, IMNV, dan PvNV), diharapkan dapat menghindari introduksi penyakit virus di Indonesia.

\section{KESIMPULAN}

1. Hasil diagnosa yang diperoleh memperlihatkan bahwa $75 \%$ sample terinfeksi IMNV, 100\% terinfeksi IHHNV dan 75\% kasus multi infeksi IHHNV dan IMNV pada budidaya udang L. vannamei.

2. Kasus multi infeksi IHHNV dan IMNV tidak menimbulkan kematian massal pada udang L. vannamei.

3. Penggunaan sampel dengan preservasi yang tepat dan primer spesifik, dapat meningkatkan validitas diagnosa

\section{SARAN}

1. Dalam kebijakan kedepan harus diupayakan standarisasi diagnosa untuk seluruh laboratorium yang ada di Indonesia.

2. Perlu adanya pemantauan rutin dengan standar diagnosa akan adanya infeksi virus pada udang introduksi L. Vannamei.

3. Perlu adanya kontrol yang ketat terutama import udang jenis L. vannamei untuk mencegah introduksi penyakit baru.

\section{UCAPAN TERIMA KASIH}

Diucapkan terima kasih kepada laboratorium beserta staf Hans- Knoll Institute (HKI) Jena Germany yang sudah memberikan kesempatan dalam melakukan diagnosis dalam penelitian tersebut di atas.

\section{DAFTAR ACUAN}

Aquaculture Asia Pacific March/April. 2010. Real- time PCR shrimp virus detection, 6(2): 46.

Bonnichon, V., Lightner, D.V., \& Bonami, J.R. 2006. Viral interference between infectious hypodermal and hematopoietic necrosis virus and white spot syndrome virus in Litopenaeus vannamei. Dis. Aquat. Org., 72: 179- 184.

Bonami, J.R., Trumper, B., Mari, J., Brehelin, M., \& Ligtner, D.V. 1990. Purification and characterization of the infectious hypodermal and hematopoietic necrosis virus of penaeid shrimps. J. Gen Virol., 71: 2,657- 2,664.

Dhar, A.K., Roux, M.M., \& Klimpel, K.R. 2001. Detection and quantification of infectious hypodermal and haematopoietic necrosis virus and white spot virus in shrimp using real- time quantitative PCR and SYBR green chemistry. Journal of Clinical Microbiology, p. 2,835- 2,845.

Flegel, T.W., Nielsen, L., Thamavit, V., Kongtim, S., \& Pasharawipas, T. 2004. Presence of multiple viruses in non-diseased, cultivated shrimp at harvest. Aquaculture, 240. 55- 68.

Flegel, T.V. 1999. An overview of prawn viral disease work in Thailand: PCR for shrimp disease diagnosis. Moleculer diagnostic for shrimp viruses in The Asian Region. ACIAR- Mahidol Univ. Thailand, L3- 1L3- 11.

Gilad, O., Yun, S., Zagmutt- vergara, F.J., Leutenegger, C.M., Bercovier, H., \& Hedrick, R.P. 2004. Concentration of a koi herpesvirus (KHV) in tissue of experimentally infected Cyprinus carpio koi as assessed by real- time TagMan PCR. Diseases of Aquatic Organism, 60:179- 187.

Inouye, K., Miwa, S., Oseko, N., Nakano, H., Kimura, T., Momoyama, K., \& Hiraoka, M. 1994. Mass mortalities of culured kuruma shrimp Penaeus japonicus in Japan in 1993: Elektron microscopic evidence of the causative virus. Fish Patologhy, 29(2): 149158. 
Kasornchandra, J., Boonyaratpalin, S., \& Itami, T. 1998. Detection of white- spot syndrome in cultured penaeid in Asia. Microscopic observation and polymerase chain reaction. Aquaculture, 164: 243- 251.

Kalagayan, H., Godin, D., Kana, R., Hagino, G., Sweeney, J., Wyben, J., \& Brook, J. 1991. IHHNV virus as an etiological factor in runtdeformity syndrome (RDS) of juvenile Penaeus vanname cultured in Hawaii. Journal World Aquaculture Society, 22: 235- 243.

Kimura, T., Yamano, K., Nakano, H., Momoyama, K., Hiraoka, M., \& Inouye, K. 1996. Detection of Panaeid Rod-shaped DNA Virus (PRDV) by PCR. Fish Pathology, 31(2): 9398.

Koesharyani, I., Supriyadi, H., Gardenia, L., Mufidah, T., \&. Aryati, Y. 2009. Aplikasi dan validasi metode diagnostik DNA virus udang IHHNV, MBV dan WSSV secara pararel dan multiplek. Laporan Penelitian APBN 2009 unpublish.

Koesharyani, I., Roza, D., Mahardika, K., Johnny, F., Zafran, \&Yuasa, K. 2001. Manual for fish disease diagnosis- II (Marine fish and Crustacean diseases in Indonesia. Gondol Research Institute for Mariculture and Japan International Cooperation Agency, 49 pp.

Lightner, D.V. \& Redman, R.M. 1998. Shrimp diseases and current diagnostic method. Aquaculture, 164: 201- 220.

Manivannan, S., Otta, S.K., Karusanagar, I., \& Karusanagar, I. 2002. Multiple viral infection in Penaeus monodon shrimp postlarvae in an Indian hatchery. Dis. Aquat. Org., 48: 233- 236.

Mote, E., Yugcha, E., Luzardo, J., Castro, F., Leclercg, G., Miranda, P., Borja, O., Serrano, J., Terreros, M., Montalvo, K., Narvaez, A., Tenorio, N., Cedeno, V., Mialhe, E., \& Boulo, V. 2003. Prevention of IHHNV vertical transmision in the white shrimp Litopenaeus vannamei. Aquaculture, 219: 57- 70.

Melena, J., Bayot, B., Betancourt, I., Amano, Y., Panchana, F., Alday, V., Calderon, J., Stern, S., Roch, Ph., \& Bonami, J.R. 2006. Pre- exposure to infectious hypodermal and hematopoietic necrosis virus or to inactivated white spot syndrome virus (WSSV) confers protection against WSSV in Penaeus vanname (Boone) post- larve. Journal of Fish Diseases, 29: 589- 600.

Natividad, K.D.L., Migo, M.V.P., Albaladejo, J.D., Magbanua, J.P.V., Nomura, N., Matsumura, M. 2006. Simultaneous PCR detection of two shrimp virus (WSSV and MBV) in post larvae of Penaeus monodon in the Philippines. Aquaculture, 257: 142- 149.

Novita, H., Mufidah, T., \& Koesharyani, I. 2009. Perbandingan penggunaan berbagai preservasi RNA jaringan dengan RNAlater, alkohol dan alkohol- gliserol untuk deteksi IMNV dengan PCR. J. Ris. Akuakultur, 4(3): 377- 383.

OIE. 2006. Mannual of Diagnostic Test for Aquatic Animal, World Organisation for Animal Health, $414 \mathrm{pp}$.

Poulos, B.T., Kibler, R., Bradley, D., Dunlop, Mohney, L.L., \& Liggtener, D.V. 1999. Production and use of antibiodies for detection of Taura syndrome virus in penaid shrimp. Dis. Aquat. Org., 37: 99- 106.

Poulos, B.T., Tang, K.F.J., Pantoja, C.R., Bonami, J.R., \& Lightner, D.V. 2006. Purification and characterization of infectious myonecrosis virus of penaeid shrimp. Journal of General Virology, 87: 987- 996.

Poulos, B.T. \& Lightner, D.V. 2006. Detection infection with infectious myonecrosis virus (IMNV) of penaeid shrimp by ReverseTranscriptase Polymerase Chain Reaction (RT- PCR). Dis. Aquat. Org., 73: 69- 72.

Rodriguez, J., Bayot, B., Amano, Y., Panchana, F., I de Blas, Alday, V., \& Caledron, J. 2003. White spot syndrome virus infection in cultured Penaeus vanname (Boone) in Ecuador with emphasis on hstopathology and ultrasucture. Journal of Fish Diseases, 26: 439- 450.

Senapin, S., Phewsaiya, K., Briggs, M., \& Flegel, T.W. 2007. Outbreaks of infectious myonecrosis virus (IMNV) in Indonesia confirmed by genome sequencing and use of an alternative RT- PCR detection method. Aquaculture, 266: 32- 38.

Teng, P.H., Lee, P.Y., Lee, F.C., Chien, H.W., Chen, M.S., Sung, P.F., Su, C., \& Ou, B.R. 2006. Detection Oh infectious hypodermal and hematopoietic necrosis virus (IHHNV) in Litopenaeus vanname by ramification amplification assay. Dis. Aquat. Org., 73: 103- 111.

Tang, K.F.J., Navarro, S.A., \& Lightner, D.V. 2007 a. PCR assay for discrimenitating between infectious hypodermal and hematopoeitic necrosis virus (IHHNV) and virus - related sequences in the genome of Penaeus monodon. Dis. Aquat. Org., 74: 165- 170.

Tang, K.F.J., Pantoja, C.R., Redman, R.M., \& Lightner, D.V., 2007 b. Development of in 
situ hybridization and RT- PCR assay for the detectionof a nodavirus (PvNV) that causes muscle necrosis in Penaeus vanname. Dis. Aquat. Org., 75: 183- 190.

Tang, K.F.J., Pantoja, C.R., Poulos, B.T., Redman, R.M., \& Lightner, D.V. 2005. In situ hybridization demonstrates that Litopenaeus vanname, L stylirostris, and Penaeus monodon are susceptible to experimental infection with infectious myonecrosis virus (IMNV). Dis. Aquat. Org., 63: 261- 265.
Tang, K.F.J., Poulos, B.T., Wang, J., Redman, R.M., Shih, H.H., \& Lightner, D.V. 2003. Geographic variation among infectious hypodermal and hematopoeitic necrosis virus (IHHNV) isolates and characteristics of their infection. Dis. Aquat. Org., 53: 91- 99.

Tretiakov, A. \& Saluz, H.P. US Patent 6,556,940). SpeedyCycler PCR Machine. 